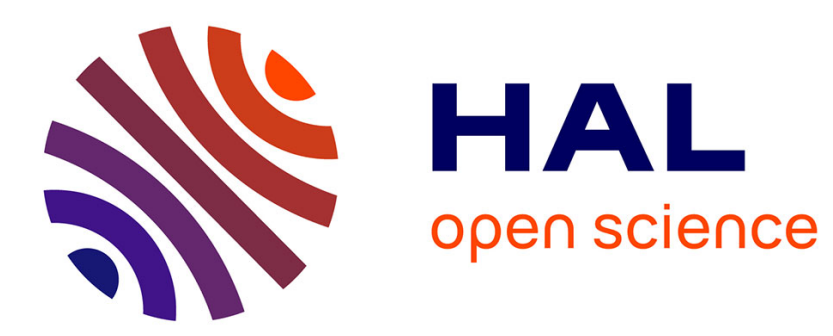

\title{
Globalisation, Social Welfare, Public Policy and Labor Inequalities
}

Clement Allan Tisdell, Serge Svizzero

\section{To cite this version:}

Clement Allan Tisdell, Serge Svizzero. Globalisation, Social Welfare, Public Policy and Labor Inequalities. The Singapore Economic Review, 2004, 49 (02), pp.233-253. 10.1142/S0217590804000901. hal-02153097

\section{HAL Id: hal-02153097 https://hal.univ-reunion.fr/hal-02153097}

Submitted on 12 Jun 2019

HAL is a multi-disciplinary open access archive for the deposit and dissemination of scientific research documents, whether they are published or not. The documents may come from teaching and research institutions in France or abroad, or from public or private research centers.
L'archive ouverte pluridisciplinaire HAL, est destinée au dépôt et à la diffusion de documents scientifiques de niveau recherche, publiés ou non, émanant des établissements d'enseignement et de recherche français ou étrangers, des laboratoires publics ou privés. 


\title{
GLOBALIZATION, SOCIAL WELFARE, PUBLIC POLICY AND LABOR INEQUALITIES
}

\author{
CLEM TISDELL \\ School of Economics, The University of Queensland, Brisbane, 4072 Australia \\ c.tisdell@economics.uq.edu.au \\ SERGE SVIZZERO \\ University of La Reunion
}

\begin{abstract}
Income inequality has increased sharply in higher income and in many lower income countries. Theories attributing this to bifurcation of labor markets in higher income countries are examined. Some theorists attribute this bifurcation primarily to technical change with influence from globalization. Others take an opposite viewpoint. A contrasting view presented here is that globalization is strongly linked with technological change. More significantly even if globalization increases economic efficiency and growth in globalizing countries, it can raise income inequality and reduce social welfare in such countries. International fiscal competitiveness may, it is argued, contribute to income inequality and make all nations worse off. Trends in public social expenditure and in taxation receipts in higher income countries, including Singapore, are examined to determine the extent of empirical support for the theory.
\end{abstract}

Keywords: Fiscal competition; globalization; income inequality; labor markets; public economics.

\section{Introduction}

The belief is widespread that structural adjustment policies and globalization will increase economic efficiency and social welfare. Furthermore, in some countries, for example, in Australia, it is commonly thought that more competition in labor markets can foster employment by raising international competitiveness of the production of traded commodities. In addition, some nations, for example, Ireland, appear to be engaged in international fiscal competition, through the lowering of tax rates to encourage foreign direct investment and business investment.

This article points out that increased market competition and globalization, even if they raise economic efficiency and stimulate economic growth, may reduce social welfare in high income and other countries. Furthermore, growing market competition associated with globalization may result in little increase in employment, as well as uneven income and employment benefits and opportunities between professional and highly skilled personnel, and unskilled laborers. Laborers disadvantaged by this process may have been further disadvantaged by some reduced public social expenditures in higher income countries in recent decades. In addition, it is possible that international fiscal competition as a result of growing economic globalization has contributed in some nations to reduced provision of government 
services that includes in most cases, welfare services, and can result in prisoners' dilemmalike problems resulting in a Paretian inferior outcome globally. Each of these related matters will be examined in turn analytically and then assessed on the basis of international empirical evidence.

\section{Increasing Income Disparities and Labor Market Inequalities in OECD Countries}

It is well documented that since the 1970s, OECD countries have exhibited economic growth and growing income inequalities. See, for example, Svizzero and Tisdell (2002, 2003) and references there. This is contrary to Kuznets' (1955) theory. To a considerable extent, this trend is reflected in the growing divergence in conditions of work for skilled employees compared to unskilled workers or those with limited skills. Depending on the countries concerned, these differences are reflected in diverging wage or salary levels, widening levels of non-wage entitlements, growing gaps in job security and differences in unemployment rates with low skilled employees being relatively disadvantaged.

The need to modify Kuznets' theory of the relationship between economic growth and income inequality is evident, for example, from US data. Somewhere in the 1970s or early 1980s (depending on how income inequality is measured) income inequality in the US began to rise markedly although it displayed the characteristics predicted by the Kuznets' inverted-U curve from 1920 until the new turning point involving increasing income inequality was encountered (cf. Kuznets, 1953, p. 635; Mishell et al., 2001, p. 50; Brinkman and Brinkman, 2001, p. 117). Whereas in the early 1980s, the highest $5 \%$ of income earners in the United States accounted for around $14.5 \%$ of aggregate income, by the late 1990s, they accounted for over 25\% (cf. Brinkman and Brinkman, 2001, p. 17; US Census Bureau, 2000, Table F-2). Using the Gini coefficient as a measure of inequality, Mishell et al. (2001, p. 17) found that the trend in the US was for income inequality to decline from 1947 until the beginning of the $1970 \mathrm{~s}$ at a decreasing rate, then to rise, first at an accelerating rate and then at a declining rate. By the end of the 1990s, income inequality in the US was much greater than in the 1950s and 1960s. Ryscavage (1999), using Gini coefficients, also found that income inequality in the US at the end of the 20th century rose sharply from its level in the 1950s and 1960s to reach a level comparable to that in the US at the end of the 1920s, a period of marked inequality.

As mentioned earlier, there is considerable evidence also of a similar rise in income inequality in other OECD countries compared to the level of inequality that existed prior to the 1970s. Moreover, income inequality has risen in many developing countries in recent times (see, for example, Ghosh, 2004) and this seems to be associated with their development of more open economies. However, Sala-i-Martin (2002) argues that globally income inequality has declined. This is nonetheless at odds with some other findings. Dowrick and Akmal (2001), for example, cite studies which support the opposite point of view. No conclusive evidence about trends in global income inequality is available. Results can vary with the type of measures of inequality used and no doubt the welfare implications of such inequality will also depend on the characteristics of the dispersion. Furthermore, from a political-social welfare point of view, inequality of income with a nation may be of more 
relevance than that between nations. It is rising income inequality within nations that is the focus of attention in this paper.

The within-national empirical evidence suggests that if a stable Kuznets' type relationship exists, it is more akin to a reclining inverted S-curve, such as curve ABCD in Figure 1, than a reversed U-curve. The segment DE is added to the modified Kuznets' curve, ABCD, in Figure 1 to allow for the deceleration observed by Mishell et al. (2001) in the US. Why has income inequality increased in high income countries since the mid-1970s, how is the relationship related to economic globalization and what are its consequences for economic welfare in high income countries?

Using world exports as a percentage of world GDP to indicate the extent of economic globalization, it is apparent from Figure 4 (see beginning of Section 6) that after remaining relatively stationary in the 1960 s and early 1970 s at around $12 \%$, this ratio shot up to almost $20 \%$ around the mid-1970s. Furthermore, although this ratio has fluctuated since then, its general trend since the mid-1970s has been upward, and it has remained well above its levels in the 1950s, 1960s and early 1970s. It is apparent that increased income inequality is associated with a significant rise in economic globalization. But positive correlation does not imply causation.

Controversy exists about the reasons for this growing income inequality in OECD countries. Some writers attribute these trends primarily to technical change in developing countries that reduced the demand for semi-skilled and unskilled labor, rather than processes of globalization (Lawrence and Slaughter, 1993; Krugman, 1996; Aghion and Williamson, 1998; Slaughter, 1998; Dawkins and Kenyon, 2000) whereas others see globalization as the prime influence, but not necessarily the only important influence on the trend (Sachs and Shatz, 1994; Wood, 1998). However, the latter seems to be in the minority in the economic literature.

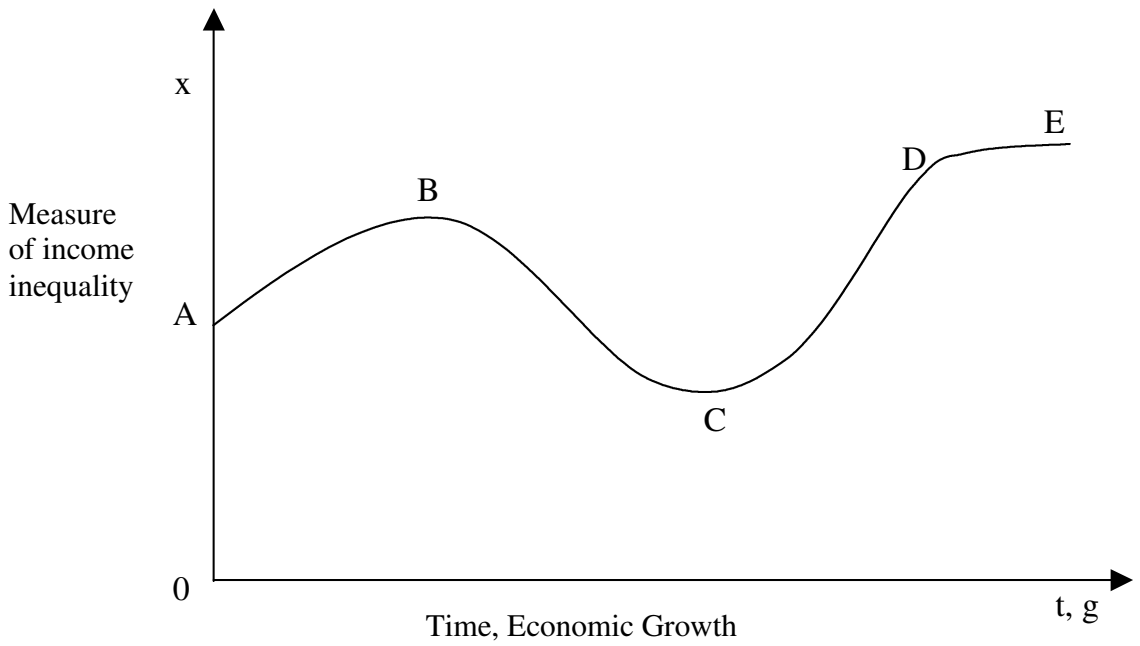

Figure 1. A “New” Kuznets' Relationship 
In practice, it may be impossible to determine how much of the divergence in labor markets in OECD countries is due to technical progress divorced from globalization, and how much is due to the process of globalization. Both factors may well be important in explaining the bifurcation of labor markets, and to a considerable extent, technical change itself is influenced by the globalization process.

Slaughter (1998, p. 1452) claims that "the consensus is that trade accounts for a positive yet relatively small share of the rising inequality" between more-skilled and less-skilled workers. However, this view is not shared by all, and one cannot conclude from it that the process of economic globalization is not an important contributor to the bifurcation of labor markets in OECD countries because globalization involves much more than reduced barriers to trade. In fact, Wood (1998, p. 1468) marshals persuasive evidence that "the main cause of the rise in labor market inequalities [in OECD countries] is globalization".

The Hecksher-Ohlin model in conjunction with the Samuelson-Stolper Theorem (Stolper and Samuelson, 1941; Samuelson, 1948) provides a possible explanation of the bifurcation process. As a result of reduced barriers to trade, and the operation of the Samuelson-Stolper Theorem, labor in plentiful supply internationally (namely unskilled labor or low-skilled labor) should find that its net wage declines in developed countries whereas the income of professionals and of highly skilled persons rises because their labor is in short supply internationally. One might expect unskilled labor-intensive industries to decline in more developed countries and industries using higher intensities of human capital to expand. Given increased mobility of physical capital, even industries with high physical capital intensities may not be retained by more developed countries unless professional/human capital complementary requirements make this desirable.

Several authors, however, argue that the operation of the Samuelson-Stolper Theorem within the Hecksher-Ohlin framework contributes little to explaining the bifurcation process. Dawkins and Kenyon (2000, p. 8) argue that the Stolper-Samuelson Theorem is not satisfied because the ratio of unskilled to skilled has not increased in all industries. Aghion and Williamson (1998, pp. 42-43) claim that trade is not a significant explanation because the demand for unskilled workers has declined in all industries, including the non-traded sectors which do not compete with developing countries and Krugman (1996, Ch. 3), argues that an explanation based on the Samuelson-Stolper Theorem is inadequate.

On the other hand, Wood (1998, pp. 1465-1466) states that the Samuelson-Stolper principle plus the presence of "defensive-innovation" in higher income countries explains the bifurcation. Defensive innovation in more developed countries results in reduced employment of unskilled labor. There is also a tendency of industries with high intensities of unskilled labor use to move offshore from higher income countries as globalization proceeds. In addition, increased outsourcing to labor-surplus countries of components of production incorporating high relative use of low-skilled labor is liable to occur with globalization. As shown by Feenstra (1998, p. 32), as soon as trade in intermediate inputs is allowed, "globalization has an impact on employment and wages that are observationally equivalent to the changes induced by technological innovation". In other words, the introduction of outsourcing helps to explain why via the globalization process the demand for unskilled 
workers has declined in all industries including the non-traded sectors. Furthermore, globalization has improved the bargaining position of capital relative to lower-skilled labor in higher income countries. Feenstra (1998, p. 46) observes that "the impact of globalization on changing the bargaining position of labor and capital has far reaching consequences". The decline in union power within trade-impacted industries may well account for a portion of the increased wage inequality in the United States (Borjas and Ramey, 1995), and possibly in Australia. Feenstra (1998, pp. 47-48) also points out that "the decision of companies to spread production across countries [by outsourcing] has distributional consequences that cannot be ignored. The position of low-skilled workers in industrial countries is worsened by a complementary combination of globalization and new technology".

An important issue is to determine to what extent technical change is biased against unskilled or lower-skilled labor, to consider the extent to which globalization promotes this bias and to identify the mechanisms arising from globalization that help generate this bias. Wood (1998) suggests that the technological bias is a defensive reaction of firms in OECD countries to competition arising from globalization. This may be so in some cases. But this bias may also be the result of proactive competitive strategies of multinational companies headquartered in higher income countries, rather than purely a result of a defensive reaction.

Globalization increases market competition and widens opportunities for foreign direct investment and trade in intellectual knowledge. It may foster benefits from the neotechnology elements of international trade and enhance the opportunities for temporary monopoly profits from international trade and investment based on new technologies (cf. Posner, 1961; Hufbauer, 1996; Teubal, 1975). Such technologies are likely to be knowledgeintensive, involving components of knowledge and highly skilled labor embodied in equipment, rather than requiring much unskilled labor for their production and use. It is likely to be easier to patent such technologies and/or defend property rights in these than in the case of technologies that make intensive use of low-skilled or unskilled labor. Globalization, by both extending the market for goods and services produced by knowledge-intensive technologies, as well as extending the scope for foreign direct investment or other forms of commercial transfer of such technology, helps promote technological change that is biased against the employment of unskilled labor.

In addition, increased international competition may also reduce the length of time for which monopoly-profits can be earned from new technologies. Thus companies must accelerate their processes of technical advance unless their profits are to fall. This treadmill effect further increases the bias against the employment of unskilled labor. If this view is accepted, it would follow that while bias against unskilled or low-skilled labor and in favor of skilled labor would arise from technical change in the absence of significant globalization, increasing globalization greatly strengthens this tendency. This hypothesis does not appear to be inconsistent with the findings of Bound and Johnson (1982) nor with those of Berman et al. (1994) which emphasize the importance of biased technological progress for labor market bifurcation.

Observe that countries that are technological leaders globally (the more developed countries) have been in the forefront of efforts to internationalize the world economy. 
Globalization provides market expansion opportunities for their technologically advanced industries, even though at the same time these countries have experienced severe labor market bifurcation. Furthermore, this process of globalization generates self-reinforcing tendencies. It increases the potential economic profits from a new international saleable product or technique, yet it simultaneously increases international competition, thereby making continual innovation by firms even more necessary to ensure the long-term survival of many firms. Thus, globalization may accelerate the treadmill of technological change and reinforce its bias against the use of unskilled or low-skilled labor in higher income countries. This is particularly so because property rights in technologies that are skill intensive are likely to be easier to protect than those for technologies that are not.

\section{More on Labor Market Inequality, Globalization and Job Security}

The Samuelson-Stolper model implicitly assumes that the employment and incomes of individuals depends on traded commodities only - commodities not traded internationally are not considered. For example, if account is taken only of internationally traded commodities, it suggests that the incomes of professionals and highly skilled workers (in short supply internationally) rise as a result of globalization and those of unskilled workers (in plentiful supply internationally) fall. But the demand for commodities not traded internationally should be considered. The higher income of the "privileged" group (professionals and skilled persons) may result in their increased demand for non-traded services provided by the group with lower skills. This back surge of demand will help to counteract the fall in income and employment of the latter group. Whether it will more than counteract it depends on the circumstances. The counter-effect will be stronger the larger is the professional/skilled group in relation to the unskilled one, other things being equal. Naturally, the counter-effect will be weakened if "guest" workers are allowed to provide the non-traded commodities that would otherwise be provided by domestic workers.

There are claims, for instance, that immigration of unskilled workers to the United States has reduced working conditions for the least educated workers there (Borjas et al., 1997). In addition, continuing technological progress may reduce the demand for lower skilled workers in developed countries. It may do so (1) through the introduction of laborsaving devices, e.g., in the home; (2) by making tradeable some labor-intensive commodities that were not previously tradeable internationally, for example, some word-processing tasks; and (3) by making it easier to outsource labor-intensive components of productive processes to developing countries (cf. Wood, 1998, p. 1466).

In more developed countries, as pointed out above, professional/skilled persons, particularly those in employment, have obtained higher incomes as the process of globalization has proceeded in recent decades. An important contributor to this has been an increase in the hours of work per week of professional/skilled persons employed. By contrast, the average hours of work of unskilled workers in employment have declined on the whole and there has also been a tendency for their average weekly earnings to decline (cf. Gregory, 2000). In OECD countries, such as Australia, the counter effect mentioned above has not been large enough to compensate for the adverse effect on the non-skilled group of globalization. 
In addition, a dichotomy is present in the labor market, namely the employment of professional and skilled persons seems relatively inflexible with their average hours of work being flexible, whereas the employment of those with few skills is flexible with their hours of work also subject to flexibility.

One explanation for these differences may be found in new institutional economics and human capital theory. The market transaction costs involved in short-term adjustments of the employment of professional/skilled labor by a firm are likely to be very high compared to that for unskilled labor. Furthermore, and this is partially connected to the previous point, many of the skills acquired by professional/skilled labor in employment are firm-specific. Dismissal of a professional or skilled employee results in a large loss of firm-specific skills or expertise by the business, and when new employees are hired considerable investment is required to re-establish these skills. Thus on-the-job learning combined with the costs of the sifting or sorting process for selecting the best available professionals may mean that a business finds it profitable from a long-term point of view to be rather inflexible in its employment of professional or skilled persons and to vary their hours of work in relation to changing economic conditions, rather than to immediately employ additional staff of this kind.

This is not to say that the employment of professional and skilled persons will not be adjusted in the long run in response to rising demand for the product of a business. However, the increase is likely to involve a "smoothing" process and is less likely to occur the more uncertain is the future demand for a firm's product. In essence, the employment of new professional/skilled staff involves a significant overhead cost to most businesses. This phenomenon also helps to explain the relatively high unemployment of youth in developed countries compared to persons of more mature age (see Gregory, 1999); and the lower average hours of work of youth compared to those of greater maturity, as well as significant differences in average weekly earnings between younger and more mature persons.

Gregory (2000) has suggested that these phenomena might be explained to some extent by the fact that "bosses" belong to the older age group and may have appropriate opportunities to earn higher income in their business for themselves. Certainly, this may be so, but the sociological explanation could also be supported by explanations rooted in "new" institutional economics, human capital theory and on-the-job learning, as discussed above.

\section{Increased Economic Efficiency and Growth Accompanied by Reduced Social Welfare}

Globalization is widely believed to increase economic competition, stimulate economic growth and promote economic efficiency. Claimed advantages are an improved allocation of resources internationally and the promotion of technological progress worldwide. Nevertheless, globalization may reduce social welfare if it results in considerable inequality of income, as seems to be occurring in more developed countries and in less developed ones. It can do this in higher income countries on a major scale given its Samuelson-Stolper like impacts plus more significantly, its stimulus to the development and application of new technologies and products that reduce the use of lower-skilled labor. The increased pace of 
technological innovation and its growing bias against less-skilled labor is not just defensive as Wood (1998) suggests but more importantly is a proactive competitive reaction to globalization opening new opportunities for profiting from new technologies, especially by established multinational companies or nascent ones.

The possibility of a deterioration in the social welfare of a more developed country (or less developed one also) as a result of globalization can be illustrated by Figure 2. For simplicity, assume a two-person society (or one consisting of two groups with homogeneous members in each group) with individual one dependent on a globally plentiful resource for income and individual two on a globally scarce resource for income. Let the curve CDE represent the utility-possibility frontier for the society prior to globalization and assume that the social welfare indifference curves of the Bergson-type (Bergson, 1938) represented by $\mathrm{W}_{1} \mathrm{~W}_{1}, \mathrm{~W}_{2} \mathrm{~W}_{2}$, etc., apply. These allow for some trade-off of inequality in income. Now suppose that prior to globalization, the economy is located at point, A. It is Paretian inefficient. After globalization, its utility possibility frontier moves up to $\mathrm{C}^{\prime} \mathrm{D}^{\prime} \mathrm{E}^{\prime}$ either because a greater resource-base becomes available to it or because greater economic growth induces by globalization. Suppose now that the economy moves to point B. It is then fully efficient (in the static economic sense) and it has experienced economic growth but the social welfare of the society has declined. This happens because inequality of income after the change has increased to such an extent that the Bergson welfare function (Bergson, 1938) indicates a fall in social welfare.

Note that this result is possible even if the utility received by each of the individuals (or groups) is considered to be perfectly substitutable. This is so if the social welfare indifference curves are straight lines with a rate of indifferent substitution of unity.

However, the situation may be worse in reality than is apparent from Figure 2. For extreme inequalities in income, the utility possibility frontier may bend back on itself in

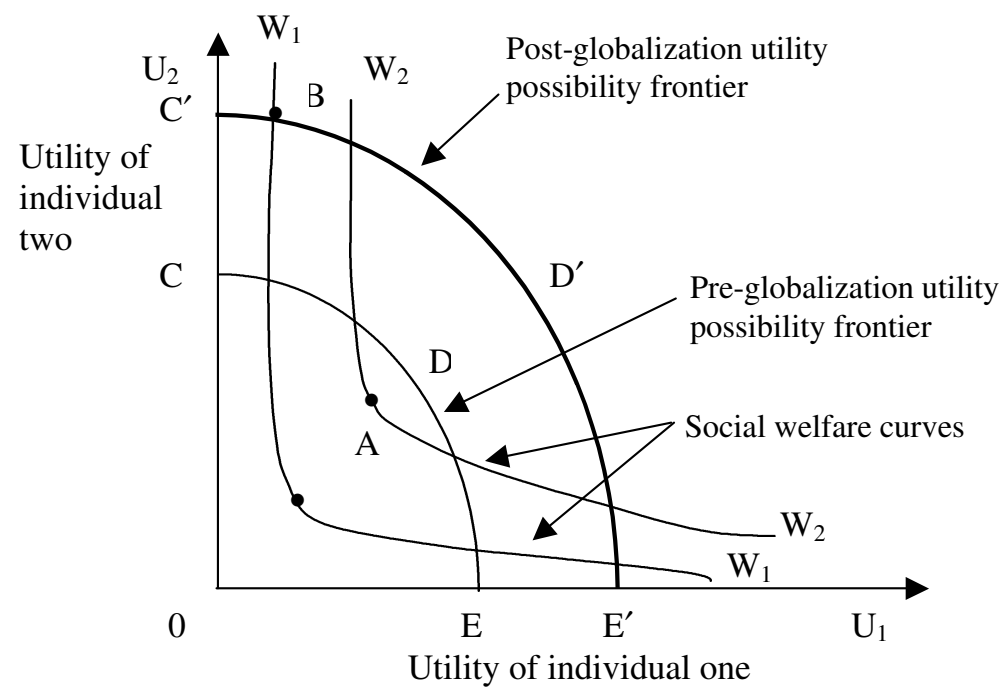

Figure 2. Decline in Social Welfare as a Result of Globalization 


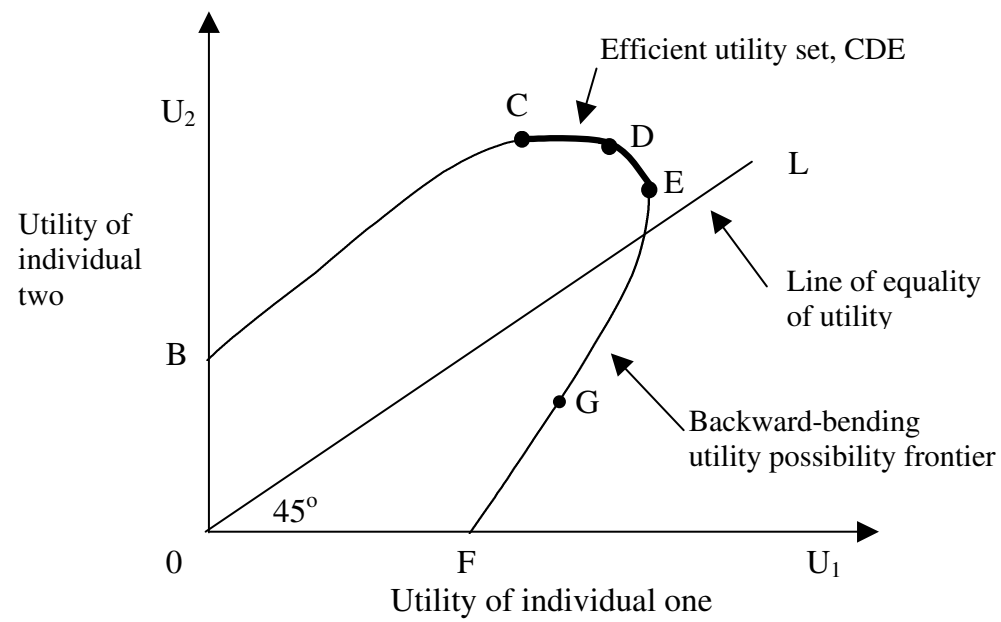

Figure 3. A Utility Possibility Frontier Showing Recurving. Gross Income Inequality Reduces Total Welfare Resulting in All Losing

the manner shown in Figure 3 by the curve BCDEF. This indicates that great inequality lowers the utility of all parties. For instance, extreme inequality could drive the economy to point G. In fact, the efficient set is only confined to the segment CDE. Note that this "recurving" effect may arise, for example, because gross inequality may increase crime or place a social welfare redistribution burden on the better-off members of the community. These consequences have disincentive impacts on production. A longer-term possibility is that such gross income inequality results in similar gross inequality in the distribution of social and human capital (e.g., lopsided access to education and health services), reduced equality of opportunity and consequently lower productivity in society.

Observe that the recurving effect does not imply that equality of income is desirable, that is, that income distribution should be along the $45^{\circ}$ line OL in Figure 3. In fact in the case shown, inequality would be optimal even if Rawlsian social indifference curves (rightangled located on OL) applied (Rawls, 1971). In fact, in this case, the Rawlsian optimum is at point $\mathrm{E}$. This implies that the optimum distribution of income would be one favoring individual two or group two.

As suggested above, the recurving productivity-depressing effect can be very serious in the long run if it is associated with reduced human capital investment in commodities such as health and education of the poorest members of society, namely the lower skilled and their children. Such an effect may occur as welfare states are dismantled, as has been increasingly thought to be so in the last couple of decades (cf. Gray, 1988). Various arguments have been advanced for governments reducing their support for social security. For example, it is sometimes argued that if a country is to remain competitive in a globalizing world, it must have a low rate of taxation and therefore, the government cannot afford much support for social services. Whether this is so is, however, debatable. For example, the argument only considers the cost side of taxation and ignores the possible economic benefits that can be obtained if public funds are spent wisely. Nevertheless, as discussed later, in 
a globalizing world, fiscal competitiveness between nations could reduce their support for social security efforts and other public programs. This can reduce the social welfare of all the nations involved.

Here, it is pertinent to note that as Brinkman and Brinkman (2001, pp. 28-29) argue, income distribution is influenced to a considerable extent by public policy, and changes in it by swings in such policy. Thus apart from globalization, political perceptions, may alter public expenditures. Certainly a holistic discussion of the subject cannot ignore questions of political economy, including changing attitudes to public social expenditures, a point also made by Kuznets (1955, p. 28).

\section{Dilemmas of International Fiscal Competitiveness: Reduced Welfare Benefits and Public Services}

In the last few decades, there has been widespread political support for the adoption of structural adjustment policies, which, amongst other things, encourage a reduction in the size of the public sector and greater reliance on markets, including global markets. Such policies are believed by some to have resulted in reduced public services and reduced provision of social welfare payments (cf. Gray, 1998). Furthermore, many countries have seen such measures as being beneficial for increasing their international competitiveness. For example, reduced company taxes and other public charges may encourage foreign direct investment in a country, if these measures are not also adopted by competitors. Furthermore, a reduction in the public cost component of exporting goods may have a favorable impact on exports and reduce imports if competing countries do not respond with fiscal concessions.

Fiscal competition can, however, give rise to a prisoners' dilemma problem. Consider a two-country case and the matrix of possibilities shown in Table 1. Each country is assumed to have two alternative strategies, no fiscal concessions and fiscal concessions, represented respectively by strategies $\alpha_{1}$ and $\alpha_{2}$ for country one and $\beta_{1}$ and $\beta_{2}$ for country two. The payoffs to each country are represented by the cell entries. If both begin from a situation of no fiscal concessions, each has a selfish interest to make such concessions. But as a consequence, a Paretian inferior outcome results which constitutes a Nash equilibrium. All are worse off as a result.

Note that in the Nash equilibrium shown in Table 1, aggregate economic benefits are lower in the fiscal competition situation than when all parties refrain from such competition. This could occur because, up to a point, public services (e.g., education, infrastructure) may be complementary to private production. Especially in the Paretian suboptimal situation, such services may be reduced to a level that lowers the overall productivity of the economy.

Table 1. A Case in which Fiscal Competitiveness Leads to a Paretian Inferior Nash Equilibrium

\begin{tabular}{lllc}
\hline & \multicolumn{3}{c}{ Strategies of Country Two } \\
& & $\beta_{1}$ & $\beta_{2}$ \\
\hline Strategies of Country One & $\alpha_{1}$ & $(5,5)$ & $(2,8)$ \\
& $\alpha_{2}$ & $(8,2)$ & $(4,4)$ \\
\hline
\end{tabular}


Furthermore, it is also likely that in a fiscal competitive situation social welfare services will be cut, resulting in sharp increases in inequality. For similar reasons to those discussed in relation to Figure 2, social welfare may fall. In addition, it is possible (see Figure 3) that failure of a society to meet the basic needs of a group of its citizens may impose increased costs on it. For example, it can do this by increasing the crime rate, by lowering productivity as a result of reduced healthiness or fitness of citizens, and can result in an increased emphasis on curative medicine rather than preventative approaches to illness. Although the payment of social welfare benefits is often considered solely as a cost to society, their provision can have productive benefits and can avert costs otherwise imposed on society when the welfare of its citizens is grossly neglected.

In relation to fiscal concessions designed to encourage business and foreign direct investment, it is pertinent to note that a conflict may exist between the short run and the long run. Much publicly provided complementary overheads, such as education and infrastructure, tend to be long-term assets. The effect of a reduction in their provision may not become obvious for some time because it takes a while for the existing stock of some public assets to decline.

In Europe, the launching of the Euro has shed new light on the problem of tax coordination. In fact, the conduct of economic policies is confronted with a new dilemma. On the one hand, freedom in capital movements puts pressure on tax rates and therefore on Governments' revenues. Indeed, due to this freedom, multinational firms become more and more sensitive to tax consideration when they decide about their operational locations. This is simply the perverse effect of tax competition. On the other hand, the Amsterdam Stability Pact requires that the public deficit of each European country remain close to zero. This strains the ability of these countries to reduce tax pressures. One "solution" to this dilemma seems to be to distinguish, for fiscal purposes, between mobile and less mobile factors of production. This deepens the degree of interdependence between tax policies. Changes of the tax rate on mobile resources or tax-bases produce externalities between countries but also have an impact on the less mobile tax-bases or resources that includes unskilled labor in higher income countries (and also sticky activities, final consumption and so on). Therefore, this "solution" could result in a greater economic burden on unskilled workers and greater income inequality because tax competition consists of lower tax rates on mobile factors (in order to attract FDI) and higher tax rates on less mobile factors (in order to maintain Government revenues).

The following provides an example of the impact of the fiscal competitiveness of Ireland on a German firm's decision on where to locate its new investment. Artur Theis GmbH \& Co. is a medium-sized company producing packaging for the pharmaceutical industry. It recently decided to establish and open a very modern plant, Theis Eire Teo in Ireland. Its managing director "Jurgen Theis selected Ireland for the new plant because there he has to tax his profits at just $10 \%$ - and not at $60 \%$ as in Germany. In addition, the staff costs, not just salaries but also the additional costs [on-costs], are considerably lower in Ireland. As a result he can achieve greater profit margins, build up larger share capital, and thus gain new customers" (Anon, 2000, p. 9). Furthermore, "he receives funds from the Irish Settlement Company in order to have his employees trained specifically for his company". 
However, the economics literature on the effects of international tax competition remains quite controversial.

In its 1998 report entitled "Harmful Tax Competition: An Emerging Global Issue", the OECD claimed that the actions on the tax systems induced by globalization imply potential distortions in the patterns of trade and investment and reduce global welfare. The report identifies, as we did above, mechanisms which support harmful preferential tax regimes (such as the shift of the tax burden from mobile to relatively immobile factors). It also provides a complete study of tax havens.

On the other side, some economists consider that competition among governments is akin to market competition for products. By extending to the international sphere Tiebout's (1956) analysis of competition between local governments for mobile households, they conclude that international tax competition enhances society's overall welfare. Furthermore, some, such as Edwards and de Rugy (2002), consider the allegation to be false that fiscal externalities are harmful because they affect global welfare. They claim that critics of international fiscal competition falsely believe that global tax policy involves zero-sum economics. Actually, however Table 1 above does not specify a zero-sum game. Some supporters of fiscal competition believe that if a country adopts a more efficient tax system to maximize growth, other countries may follow, with the result that global investment and output rise and all are better off.

For those who are in favor of restricting international tax competition, the implementation of an International Tax Organization (ITO) could be useful. In their 2001 report, the United Nations claim that such an organization might be like the WTO which handles trade disputes. It would develop norms for tax policy, engage in surveillance of tax systems, and push countries to desist from harmful tax competition. As highlighted in the 2000 OECD report "Towards Global Tax Co-operation", the purpose of such organization is not to promote harmonization among fiscal policies but to ensure that the burden of taxation is fairly shared and that tax should not be the dominant factor in making capital allocation decisions.

\section{Evidence about Trends in Public Social Expenditure and in Fiscal Competitiveness}

To recapitulate: it has been observed that income inequality increased in most OECD countries from the mid-1970s onward, a period associated with increased globalization of economic activity and considerable economic growth. It was also noted that different views exist among economists about the extent to which this growing income inequality is a result of growing economic globalization. This trend in inequality throws doubts on the wide applicability of the Kuznet's curve relationship. More importantly, analysis was presented to suggest that this growing income inequality can have negative effects on social welfare via its negative effects on the level of national production, if not immediately then in the longer term. This possibility becomes more likely when rising income inequality is accompanied by falling social welfare payments by government and reduced public social expenditure.

It was argued, theoretically, that growing economic globalization can encourage growing fiscal competition between nations resulting in falling public expenditure and eventually reduced social (economic) welfare for all. 


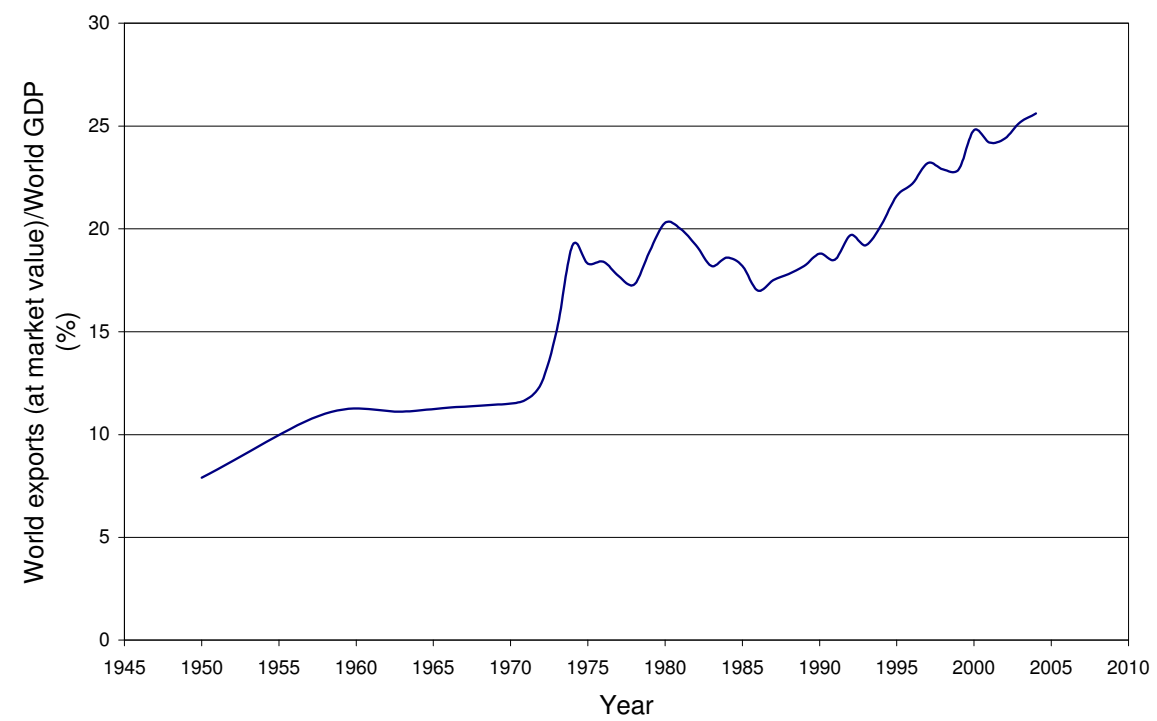

Source: The IMF World Economic Outlook Database April 2003; United Nation's Statistical Yearbook 1970; Doha WTO Ministerial 2001 Briefing Notes.

Figure 4. Generalized Graph of World Exports as a Percentage of World GDP, 1950-2004, Based on IMF, WTO, and United Nation's Statistics. The Figures for 2003 and 2004 are Estimates

Evidence of the pattern of changes in the extent of economic globalization are apparent from Figure 4, if world exports as percentage of world GDP is used to indicate the extent of economic globalization. It can be seen that economic globalization was much more marked after the mid-1970s than before this. Consequently, one might expect fiscal competition to be more evident after the mid-1970s than before this. Therefore actual public sector behavior after the mid-1970s will be compared to that in the early 1970s to see if there is evidence of greater fiscal competition in the latter period. Furthermore, a related issue is whether there is evidence that government support for the less well off in society has increased or decreased with growing income inequality and rising globalization.

Now we examine actual trends in public sector behavior since the early 1970s. Is there strong evidence of falling social security and welfare expenditure by governments over this period? Has public social expenditure fallen? Is there evidence of increasing fiscal competitiveness between nations, for instance, via reductions in their levels of taxation? Consider the evidence, from selected higher income countries.

First, it might be noted that government expenditure on social security and welfare varies greatly between higher income countries as a percentage of GDP. Table 2 provides the most recent available IMF statistics. Sweden heads this list with $18.9 \%$ of its GDP spent on social security and welfare by the government, and the US is at the bottom of the list, excluding Singapore (which spends a negligible percentage of its GDP for this purpose).

For all these countries, there has been a decline in public spending on social security and welfare as a percentage of GDP in the 1990s. Of course, a reduction in this percentage does not necessarily imply a fall in real per capita spending on social security and welfare. This, 
Table 2. Percentage of GDP Spent on Social Security and Welfare by Governments in Selected Higher Income Countries by Latest Available Years

\begin{tabular}{lc}
\hline Country & $\%$ and latest year \\
\hline Australia & $8.7(1998)$ \\
Canada & $9.7(1997)$ \\
Denmark & $14.6(1999)$ \\
France & $18.3(1993)$ \\
Germany & $16.9(1996)$ \\
Ireland & $8.6(1997)$ \\
Sweden & $18.9(1999)$ \\
UK & $13.3(1999)$ \\
USA & $5.6(1999)$ \\
Singapore & $0.1(1998)$ \\
\hline
\end{tabular}

Source: IMF Government Financial Statistics Table B6. www.worldbank.org/research/growth/GDNdata.htm (downloaded 16 April, 2003)

Table 3. Public Expenditure on Social Security and Welfare for Selected High Income Countries as a Percentage of GDP. Earliest Overlook 1970s

Observation, Maximum Percentage and Latest Available 1990 Observation Reported by IMF. Year of Observations in Brackets.

\begin{tabular}{lccc}
\hline Country & 1970s Observation & Maximum Observed & Latest Observation \\
\hline Australia & $3.9(1972)$ & $9.4(1994)$ & $8.7(1998)$ \\
Canada & $6.5(1973)$ & $12.2(1991)$ & $9.7(1997)$ \\
Denmark & $12.2(1972)$ & $18.4(1994)$ & $14.6(1999)$ \\
France & $14.9(1975)$ & $20.2(1992)$ & $18.3(1993)$ \\
Germany & $11.3(1972)$ & $15.6(1983)^{*}$ & $16.9(1998)$ \\
Ireland & $\mathrm{n} / \mathrm{a}$ & $13.0(1985)$ & $8.6(1996)$ \\
Sweden & $12.5(1972)$ & $24.8(1993)$ & $18.9(1999)$ \\
UK & $8.0(1972)$ & $15.6(1993)$ & $13.3(1999)$ \\
USA & $6.4(1972)$ & $8.3(1983)$ & $5.6(1999)$ \\
Singapore & $0.1(1972)$ & $2.2(1996)$ & $0.1(1998)$ \\
\hline
\end{tabular}

${ }^{*}$ Second highest level

Source: IMF Government Financial Statistics Table B6.

http://www.worldbank.org/research/growth/GDNdata.htm (downloaded 16 April 2003)

however, has occurred for most countries in Table 3 because growth in their real GDP was not commensurate with their reduction in public spending on social security and welfare as a percentage of GDP, and for many countries, this decline started earlier.

Examination of the IMF statistics that form the basis of Table 2 indicates that for most higher income countries, public expenditure on social security and welfare as a percentage of GDP rose substantially after the early 1970s before peaking, mainly in the first half of the 1990s, and then declining. But even after the decline, public spending of this nature 
significantly exceeded that as a percentage of GDP in the 1970s. The welfare state in most higher income countries was still far from being dismantled. This is evident from Table 3.

These empirical results indicate that in the early phase of increasing globalization and growing income inequality, most higher income countries continued to increase their public welfare support. However, in the early 1990s in most cases their welfare support started to decline. Nevertheless, with the exception of the US and disregarding Singapore, welfare support in most higher income countries on the basis of the latest available figures for the 1990s remained well above that in the early 1970s. So increasing globalization and emphasis on structural adjustment policies seem to have no effect on the level of public spending on welfare at first. Even after a decline in this expenditure or a percentage of GDP became apparent in most countries in the 1990s, the levels of expenditure of most as a percentage of GDP were well in excess of that in the 1970s. Therefore, judging from the macro-statistics, public social welfare support even towards the end of the 1990s was greater than in the 1970s in most higher income countries. Thus, in the 1990s, globalization had not yet (by any means) resulted in the virtual collapse of welfare states, even though most of their social welfare systems were under increasing pressure.

The need, however for such systems was probably rising in the 1990s with growing levels of unemployment, increasing income inequality and more regressive tax systems (cf. Heady, 2002, Center on Budget and Policy Priorities, 2002).

Two additional social expenditure items of interest are public expenditure on health as a percentage of GDP and public expenditure on education as a percentage of GDP. In most higher income countries, trends in these items have been different to some extent. In health, public expenditure on health in OECD countries was on the whole higher as a percentage of GDP in the 1980s, then in the 1970s and although again higher in the 1990s, the percentage was becoming stationary (OECD, Health Data, 2001). The OECD weighted average for this item was $6.9 \%$ in $1980,8.2 \%$ in 1975 and $8.3 \%$ in 1995 . Actually in the EU in this period, this percentage showed a small decline in 1995 compared to 1993 . It was $7.1 \%$ in 1980, 8.1\% in 1993 and $7.9 \%$ in 1995 (OECD Health Data). This may signal the start of a declining trend.

Public support for education as a percentage of GDP in most countries peaked earlier than public contributions to health. In many OECD countries, public support for education peaked in the 1970 s or early 1980 s with support tending to fall after this. ${ }^{1}$ Table 4 helps illustrate the situation for selected high income countries. The relative reduction in public support for education may partly reflect increasing support for structural adjustment policies and for the user-pays principle. Table 4 also indicates that the extent of public support for education differs significantly between higher income countries.

These results suggest that concerns about falling public support for social security and welfare and for education are not completely misplaced. As for public support of health services, a downward trend is not yet significant as judged by percentages of GDP. Whether

\footnotetext{
${ }^{1}$ One reviewer suggests that this variation could reflect changing demographic patterns. It may, to some extent.
} 
Table 4. Public Expenditure on Education for Selected High Income

Countries as a Percentage of GDP. Earliest Available 1970s

Observation, Maximum Percentage and Latest Observation Reported by IMF. Year of Observations in Brackets

\begin{tabular}{lccc}
\hline Country & 1970s Observation & Maximum Observed & Latest Observation \\
\hline Australia & $0.8(1972)$ & $2.4(1978)$ & $1.9(1998)$ \\
Canada & $0.7(1974)$ & $1.0(1982)$ & $0.4(1997)$ \\
Denmark & $4.9(1972)$ & $5.0(1974)$ & $4.3(1999)$ \\
France & $3.6(1975)$ & $3.6(1977)$ & $3.3(1993)$ \\
Germany & $0.4(1972)$ & $0.4(1972)$ & $0.2(1996)$ \\
Ireland & $\mathrm{n} / \mathrm{a}$ & $6.0(1982)$ & $4.5(1997)$ \\
UK & $0.9(1972)$ & $1.7(1994)$ & $1.4(1999)$ \\
USA & $0.6(1972)$ & $0.7(1978)$ & $0.4(1999)$ \\
Singapore & $2.5(1972)$ & $5.9(1985)$ & $3.6(1998)$ \\
\hline
\end{tabular}

Source: IMF Government Financial Statistics Table B4.

http://www.worldbank.org/research/growth/GDNdata.htm

Table 5. Taxation Revenue as a Percentage of GDP for Selected Higher Income Countries. Earliest Available 1970s Observation, Maximum Percentage and Latest 1990s Observation Reported by IMF. Year of Observation in Brackets

\begin{tabular}{lccc}
\hline Country & 1970s Observation & Maximum Observed & Latest Observation \\
\hline Australia & $19.41(1972)$ & $24.46(1987)$ & $23.19(1999)$ \\
Canada & $16.25(1973)$ & $19.37(1997)$ & $19.37(1997)$ \\
Denmark & $30.77(1972)$ & $35.30(1987)$ & $33.30(1999)$ \\
France & $31.80(1972)$ & $39.19(1997)$ & $39.19(1997)$ \\
Germany & $24.32(1972)$ & $28.30(1982)$ & $20.25(1998)$ \\
Ireland & $26.05(1972)$ & $37.15(1984)$ & $30.64(1997)$ \\
Sweden & $30.07(1972)$ & $40.10(1990)$ & $36.27(1999)$ \\
UK & $29.56(1972)$ & $35.19(1998)$ & $36.64(1999)$ \\
USA & $17.11(1972)$ & $19.55(1999)$ & $19.55(1999)$ \\
Singapore & $13.94(1972)$ & $19.08(1982)$ & $14.39(1998)$ \\
\hline
\end{tabular}

Source: IMF Government Financial Statistics Table A.IV.

http://www.worldbank.org/research/growth/GDNdata.htm (downloaded 16 April 2003)

recent trends in relation to public support for social security and welfare are a result of increased fiscal competition between nations, acceptance of structural adjustment policies, or changing priorities in public spending is difficult to determine. Possibly all have played a role. In fact, changes in public spending priorities might have played the major role.

IMF statistics actually indicate that taxation revenue as a percentage of GDP for most countries has not declined significantly with growing economic globalization and neither has public expenditure. This suggests that the main effect of economic globalization has not been on tax levels but on the composition of public expenditure.

Table 5 provides some information on tax levels as a percentage of GDP for selected higher income countries. It supports the view that government taxation revenue in relation 
to GDP has tended to rise rather than decline in most higher income countries (cf. Heady, 2000) or that the extent of decline has been minor. However, in the case of Ireland, this percentage has declined substantially since 1984. IMF statistics lead to a similar conclusion about public expenditure as a percentage of GDP.

Singapore's case is interesting because its economy is very open. Singapore's tax revenue as a percentage of its GDP has declined since the early 1980s (Asian Development Bank, 2003). This could reflect public measures to increase its international fiscal competitiveness as globalization has proceeded and it has been faced by growing international competition.

\section{Concluding Assessment}

Encouragement of globalization and increased international competitiveness has been widely embraced as a strategy to enhance economic efficiency. Most economists believe that this will increase economic welfare and some expect these policies to result in a "winwin" situation. But such an outcome seems unlikely in the near future. As argued above, in some countries, increased economic efficiency (and economic growth) could be associated with a substantial increase in income inequality that reduces social welfare, partly because of adverse effects on the level of national production.

Again, it was observed that different labor groups have had divergent economic experiences, arguably as a result of the globalization process. Employed professional/skilled persons have obtained a rise in average weekly hours of work and income whereas the less skilled in more developed countries have experienced reduced average weekly hours of work and real lower incomes. However, where the latter group is able to supply non-traded commodities in demand by the former group a counter-effect is present; even though in practice this effect has not been able to offset the decline in demand for unskilled labor in more developed countries.

Concern has been expressed above about the possibility that increased inequality of earnings being accompanied by reduced public social expenditure likely to disadvantage the poor. Evidence has been provided that public expenditure or social security and welfare as a percentage of GDP declined in the 1990s and in a few higher income countries (e.g., Ireland and the US) had already began to decline in the 1980s. This may have disadvantaged lower income-earners, ${ }^{2}$ as has increasing tax regression. Also commencing in most cases in the 1970s and in several cases in the 1980s, public expenditure on education declined as a percentage at GDP. Again, this may have comparatively disadvantaged lower income families. Together these trends suggest that the concerns raised in Section 4 of this article are not misplaced. On the other hand, public expenditure on health has on the whole shown an upwards trend as a percentage of GDP. However, in recent years in higher income countries, it is

\footnotetext{
${ }^{2}$ It was also argued above that real per capita public spending on social security and welfare has possibly declined in several OECD countries. But it may be that such spending is now better targeted in favor of the less well off. This is worthy of investigation but it is beyond the scope of the present paper. However, with falling real public per capita spending on social security and welfare in several high income countries, and in some cases, similarly for education, the public social policy importance grows of better targeting those most in need.
} 
stationary or even slightly declining (see IMF Government and Financial Statistics Table B6, http://www.worldbank.org/research/growth/GDN/data.htm). The rise in this component of public expenditure may partially reflect the presence of aging populations in most higher income countries.

Whether or not declines in the social expenditure components mentioned above arise from increasing fiscal competitiveness between nations as a consequence of growing economic globalization is unclear. However, if they do, the reactions were delayed ones because initially these components grew in magnitude as globalization proceeded before subsequently declining. Nevertheless, a negative trend eventually developed possibly in part due to concerns about international fiscal competitiveness, but reinforced by changing priorities in the allocation of public expenditure involving reduced sympathy for the apparent economic plight of others, and in the case of education, growing emphasis on the user-pays principle. To the extent that these changed social policies are a result of the need to remain internationally competitive fiscally, they can result in a "lose-lose" economic situation, as demonstrated in Section 5.

Nevertheless, rising fiscal competition has not been reflected in significant overall reductions in tax rates. Overall tax revenue as a percentage of GDP has risen in many higher income countries in recent decades. Ireland, however, showed a substantial decline in this percentage between 1984 and 1997 and this undoubtedly increased its fiscal competitiveness, particularly in the EU. Yet this did not trigger similar action by other EU members, possibly because of rigidities in political systems that limit the applicability of the simple prisoners' dilemma model outlined above. This suggests that international fiscal competition is not as strong as suggested by the simple theory outlined above.

We are in agreement with Feenstra's (1998, pp. 47-48) observation that "the position of low-skilled workers in the industrial countries is worsened by the complementary combination of globalization and new technology". On neo-technology grounds, we argue that these influences are interdependent. We are sympathetic to his view that "if we want to move beyond the possibility of [potential] Pareto gains to making actual compensation [to those adversely effected by these processes], ... we should give serious consideration to wage subsidies for low-skilled workers" (Feenstra, 1998, p. 48). Slaughter (1998, p. 1460) points out that another "commonly heard suggestion for remedying rising inequality is to endow less-skilled workers with more skills through education and training". But Slaughter has doubts, based on economic theory, that this will work. In any case, high skills cannot be imparted to all those with low skills because of differences in human abilities and characteristics. Furthermore, country-specific (fiscal) policy schemes to assist the low-skilled and others disadvantaged by processes generated by globalization could be stymied by consequential reductions in international competitiveness of individual nations starting on the process. The global success of such schemes might depend on a coordinated international political effort. If political co-operation cannot be obtained globally, it may still be possible within trade blocs, such as the EU.

Evidence has been presented indicating that public social policy (including taxation policy) has in recent years (at least in the 1990s) altered in a way that disadvantages low-skilled 
workers and their families compared to their pre-existing position. The recent changes in public support for social security have been in the opposite direction to the type of policies favored by Feenstra (1998). Furthermore, relative public support for education has been reduced. These changes, however, did not arise immediately from increasing globalization. While they may have partly been a delayed reaction to globalization, other influences, such as changing social attitudes, undoubtedly played a role. The extent to which such changes were "forced on" governments by increasing international fiscal competitiveness is unclear.

Because government tax revenue as a percentage of GDP has not declined substantially in most high income countries, first indications are that relative reduction in public social expenditure have been more a consequence of changing public priorities (values) than due to increasing international fiscal competition. On the other hand, the effect of international fiscal competition should not be judged merely by differences in aggregate taxation levels. It can affect the composition of taxation. For instance, there appears to have been a shift of the tax burden from globally mobile factors of production to globally immobile ones as a result of growing globalization. ${ }^{3}$ In addition, it seems that the composition of public expenditure may be influenced by globalization. Public expenditure may increasingly provide benefits for internationally mobile factors (for example, improved public infrastructure for globally mobile businesses) and reduced benefits for more immobile factors, such as poorly skilled individuals. Both effects on public economics or finance seem to have occurred in higher income countries. Further research to investigate these possibilities would be warranted.

The situation is undoubtedly complex, but there are good reasons to be concerned about growing inequality whether attributable to greater economic globalization, changed attitudes to public social policy, or both, or to other causes, such as biased technical change. Note, however, that the evidence presented here does not support the hypothesis that relative public social expenditure in most higher income countries (especially those in Europe) is now lower than in the early 1970s (that is prior to a significant increase in economic globalization), and that increased globalization has brought about the virtual demise of preexisting welfare states, as for example, claimed by Gray (1998). Nonetheless, the evidence does provide economic grounds for social concern. It does so because of recent unfavorable trends in the level and composition of public social expenditure have been combined with growing regression in taxation systems. When these trends are superimposed on growing income inequality since the mid-1970s, as well as high levels of involuntary unemployment in recent decades in most higher income countries, this should add to social concern.

\section{Acknowledgments}

We wish to thank the editors and reviewers of this journal for their comments and suggestions on an early version of this paper, as well as participants in the Economics Policy Forum of the National University of Singapore for their feedback on an earlier version. We are grateful for some funding and for Indo-Pacific research co-operation provided by the

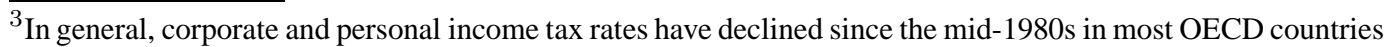
but indirect taxes, such as value added taxes, have risen (Heady, 2002) and tax systems appear to be becoming more regressive (cf. Center on Budget and Policy Priorities, 2002).
} 
French Government through its Embassy in Australia. We are grateful to Hemanath Nantha for help with data collection. The usual caveat applies.

\section{References}

Aghion, P. and J.G. Williamson (1998). Growth, Inequality and Globalization, Cambridge University Press, Cambridge.

Anon (2000). Der Ausbruch aus dem Teufelskreis. Who's Who Europa Magazin, 4, pp. 6-9.

Berman, E., J. Bound and Z. Griliches (1994). Changes in the Demand for Skilled Labor with US Manufacturing: Evidence from the Annual Survey of Manufactures. Quarterly Journal of Economics, 109, pp. 367-397.

Asian Development Book (2002). Singaporean Government Revenue. http://www.adb.org/Documents/Books/Key_indicators/2002/SIN.xi5

Bergson, A. (1938). A Reformulation of Certain Aspects of Welfare Economics. Quarterly Journal of Economics, 52, pp. 310-334.

Borjas, G, R. Freeman and L. Katz (1997). How Much do Immigration and Trade Affect Labor Market Outcomes? Brookings Papers on Economic Activity, 1, pp. 1-85.

Borjas, G.J. and V. Ramey (1995). Foreign Competition, Market Power and Wage Inequality. Quarterly Journal of Economics, 90, pp. 1075-1110.

Bound, J. and G. Johnson (1992). Changes in the Structure of Wages in the 1980's: An Evaluation of Alternative Explanations. American Economic Review, 82(3), pp. 371-372.

Brinkman, R.L. and J.E. Brinkman (2001). Cultural Lag: A Relevant Framework for Social Justice (mimeo). A paper presented to the 76th Western Economic Association International Conference held in San Francisco, 4-8 July, 2001.

Center on Budget and Policy Priorities (2002). State Tax Systems Are Becoming Increasingly Inequitable, 16 January. http://www.cbpp.org/1-15-02sfp-pr.htm

Dawkins, P. and P. Kenyon (2000). Globalization and Labour Markets: Implications for Australian Public Policy. GLM Research Paper 2000/7, Centre for Research on Globalization and Labour Markets, University of Nottingham.

Dowrick, S. and M. Akmal (2001). Contradictory Trends in Global Income Inequality: A Tale of Two Biases (mimeo). Faculty of Economics and Commerce, Australian National University.

Edwards, C. and V. de Rugy, (2002). International Tax Competition. In J. Gwartney and R. Lawson (eds.), Economic Freedom of the World: 2002 Annual Report, Cato Institute. http://www.cato.org/economicfreedom/2002/efw02-ch3.pdf

Feenstra, R.C. (1998). Integration of Trade and Disintegration of Production in the Global Economy. Journal of Economic Perspectives, 12(4), pp. 31-50.

Ghosh, B.N. (2004). Globalized Capital Development and Income Inequalities. In C. Tisdell and R. K. Sen (eds.), Economic Globalization, Edward Elgar, Cheltenham UK, pp. 210-226.

Gray, J. (1998). False Dawn: The Delusions of Global Capitalism, Granta, London.

Gregory, R. (1999). Competing with Dad: Changes in the Intergenerational Distribution of Male Labour Market Income. Discussion Paper No. 400, Centre of Economic Policy Research, Australian National University, Canberra.

Gregory, R. (2000). Labour and the New Economy: Show Me the Money, Show Me the Jobs. The Tenth Colin Clark Memorial Lecture, Department of Economics, The University of Queensland, Brisbane, 4072, Australia.

Heady, C. (2002). The Truth About Tax Burdens. OECD Observer, March 1. http://www.oecdobserver.org/news/printpage.php/aid/651/The_truth_about_tax_burdens.html

Hufbauer, G.C. (1966). Synthetic Materials and the Theory of International Trade, Duckworth, London. 
Krugman, P. (1996). Pop Internationalism, The MIT Press, Cambridge, MA.

Kuznets, S. (1953). Shares of Upper Income Groups in Income and Swings. National Bureau of Economic Research, New York.

Kuznets, S. (1955). Economic Growth and Income Inequality. American Economic Review, 45, pp. $1-28$.

Lawrence, R. and M. Slaughter (1993). International Trade and American Wages in the 1980s: Giant Sucking Sound or Small Hiccup? Brookings Papers: Microeconomics, 2, pp. 161-210.

Mishell, L., J. Bernstein and J. Schmitt (2001). The State of Working America 2000-2001, Cornell University Press, Ithaca, New York.

OECD (1998). Harmful Tax Competition. An Emerging Global Issue. 80 pages. http://www.oecd.org/pdf/M00004000/M00004517.pdf

OECD (2000). Towards Global Tax Co-operation. 31 pages. http://www.oecd.org/pdf/M000014000/M00014130.pdf

Posner, M.V. (1961). International Trade and Technical Change. Oxford Economic Papers, 13, pp. 323-340.

Rawls, J.R. (1971). A Theory of Justice, Harvard University Press, Cambridge, MA.

Ryscavage, P. (1999). Income Inequality in America: An Analysis of Trends, M.E. Sharpe, New York.

Sachs, J.D. and H.J Shatz (1994). Trade and Jobs in U.S. Manufacturing. Brookings Papers on Economic Activity, 1, pp. 1-69.

Sala-i-Martin, X. (2002). The Disturbing 'Rise' of Global Income Inequality. NBER working paper No. 8904, National Bureau of Economic Research, Cambridge, MA.

Samuelson, P.A. (1948). International Trade and Equalization of Factor Prices. Economic Journal, 59, pp. 181-197.

Slaughter, M.J. (1998). International Trade and Labour-Market Outcomes: Results, Questions and Policy Options. The Economic Journal, 108, pp. 1452-1462.

Stolper, W.F. and P.A. Samuelson (1941). Protection and Real Wages. Review of Economic Studies, 9, pp. 58-74.

Svizzero, S. and C. Tisdell (2002). Reconciling Globalization and Technological Ghange: Growing Income Inequalities and Remedial Policies. Intereconomics, 37(3), pp. 162-171.

Svizzero, S. and C. Tisdell (2003). Income Inequality Between Skilled Individuals. International Journal of Social Economics, 30, 1118-1130.

Teubal, G.C. (1966). Towards a Neotechnology Theory of Comparative Costs. Quarterly Journal of Economics, 89, pp. 414-431.

US Census Bureau (2000). March Current Population Survey, 2000. http://www.census.gov

C. Tiebout (1956). A Pure Theory of Local Expenditures. Journal of Political Economy, October, pp. 416-424.

United Nations (2001). Recommendations of the High-Level Panel on Financing for Development. New York, 22 June. http://www.un.org/reports/financing/

Wood, A. (1998). Globalization and the Rise in Labour Market Inequalities. The Economic Journal, 108, pp. 1463-1482. 